\title{
OS MEIOS DE FACILITAÇÃO DA DEFESA DOS DIREITOS DOS CONSUMIDORES
}

\section{THE DEFENSE OF FACILITATION MEANS OF CONSUMER RIGHTS}

\author{
${ }^{1}$ Josinaldo Leal de Oliveira
}

\section{RESUMO}

O estudo do direito do consumidor é sempre fascinante, haja a vista a constituição de relevantes direitos tutelados na norma de consumo em prol de um sujeito específico e vulnerável: o consumidor. Porém, para assegurar a materialização desses direitos e efetivar o sistema protetivo é preciso identificar quais sãos os meios de facilitação da defesa dos direitos dos consumidores. Nesse particular, faz-se necessário verificar quais mecanismos foram previstos no Código de Defesa do Consumidor para assegurar a efetivação dos direitos historicamente conquistados pelos consumidores. Por certo, o legislador infraconstitucional, atento as exigências constitucionais, concedeu ampla proteção no aspecto processual e material ao consumidor. O presente trabalho demonstra expressiva utilidade jurídica, na medida em que a grande preocupação do operador do direito atualmente é conseguir implementar a máxima efetividade da norma de consumo. O escrito destina-se a todos os operadores do Direito.

Palavras-chave: Facilitação de defesa, Aspecto processual, Defesa do consumidor

\begin{abstract}
The consumer rights of the study is always fascinating, there is a view to drawing up relevant rights protected in the consumer standard in favor of a specific and vulnerable subject: the consumer. However, to ensure the realization of these rights and carry the protective system is necessary to identify which sound means of facilitating the defense of consumer rights. In this regard, it is necessary to determine which mechanisms have been provided for in the Consumer Protection Code to ensure the realization of the rights historically achieved by consumers. Of course, the infra legislator, careful constitutional requirements, has given ample protection from the procedural and material aspect to the consumer. The present work demonstrates a significant legal use, to the extent that the great concern of the operator's right is currently able to implement the maximum effectiveness of the consumption standard. The brief is intended to all legal professionals.
\end{abstract}

Keywords: Defense facilitation, Procedural aspects, Consumer defense

\footnotetext{
${ }^{1}$ Doutor em Ciências Jurídicas e Sociais pela Universidad del Museo Social Argentino - UMSA, Buenos Aires (Argentina). Professor pela Faculdade Anisio Teixeira - FAT, Bahia (Brasil). E-mail: leal.mla@gmail.com
} 


\section{INTRODUÇÃO}

O Direito do Consumidor tem se apresentado como um ramo moderno e diferenciado do Direito, principalmente em razão de regular as relações jurídicas que envolvem um sujeito especial, o consumidor.

O sistema jurídico brasileiro, atendendo a um comando constitucional instituiu relevantes direitos para os consumidores que para serem efetivados passou a exigir uma relativização da estrutura processual geral.

Contudo, para a devida compreensão do sistema de consumo torna-se necessário verificar as peculiaridades processuais introduzidas pela Lei 8.078/90, revelando o caráter especializado desse ramo do direito.

O presente escrito tem o propósito de permitir ao leitor uma compreensão dos aspectos processuais relevantes do sistema de defesa do consumidor, entendendo as peculiaridades que buscam permitir a efetivação dos direitos previstos na norma consumerista. Para um melhor entendimento, o trabalho foi estruturado em tópicos gerais e específicos.

$\mathrm{Na}$ primeira parte do trabalho buscou-se demonstrar a estrutura da tutela processual individual e coletiva do direito do consumidor, apresentando a sistemática adotada pelo Código de Defesa do Consumidor brasileiro.

No segundo momento, destacou-se os meios de facilitação da defesa dos direitos dos consumidores, analisando os aspectos processuais relevantes incidentes no sistema jurídico consumerista. Nessa abordagem, foram apresentados os instrumentos utilizados para a anunciada efetivação dos direitos consagrados na norma protetiva.

\section{A TUTELA PROCESSUAL INDIVIDUAL E COLETIVA DO CONSUMIDOR}

O Código de Defesa do Consumidor brasileiro ganhou destaque no cenário jurídico mundial ao apresentar um caráter principiológico marcante, consagrando direitos relevantes e expressivos, com o fito de proteger o consumidor.

Contudo, de nada adiantaria uma norma moderna instituir direitos e garantias se o sistema jurídico permanecesse preso a uma estrutura processual tradicional, que não atentasse a dificuldade do consumidor alcançar a efetividade dos seus direitos. De forma peculiar Sérgio Cavalieri Filho ponderou:

\footnotetext{
É universalmente consagrado o entendimento de que os direitos materiais básicos do consumidor devem corresponder as garantias processuais indispensáveis à sua efetivação. Sem essas garantias processuais, os direitos materiais tornam-se normas
} 
programáticas sem maior contato com a realidade e o cotidiano dos cidadãos. Não basta, portanto, garantir a defesa do consumidor no plano material; é preciso garantila também no plano processual. (2011, p. 340).

Nessa concepção o Código de Defesa do Consumidor navegou por um norte diferenciado, revisitando institutos processuais com o fito de permitir celeridade na tramitação judicial, bem como permitir a efetivação dos direitos consagrados na norma consumerista.

Atendendo ao preceito constitucional previsto no art. 5, XXXII, o legislador infraconstitucional editou o Código de Defesa do Consumidor abarcando tanto o consumidor individual quanto ao consumidor coletivo.

A tutela individual do consumidor é bem instrumentalizada no âmbito do Código de Defesa do Consumidor, tendo em vista que por determinação legal foram criados instrumentos para consagração da política nacional de proteção e defesa do consumidor.

É preciso constatar que a legislação protetiva apresenta aspectos efetivos de um microsistema jurídico. Além da tutela civil, identificada na norma de conteúdo material, tais como as que se refere aos direitos básicos, a responsabilidade civil, a regulação contratual, dentre outras; tem-se a tutela penal, a administrativa e a processual, que apresenta normas com providencias individuais e coletivas.

A partir da década de noventa percebeu-se uma maior busca por parte dos consumidores dos seus direitos previstos em lei, valendo-se muitos consumidores dos serviços prestados pelos órgãos de proteção e defesa do consumidor, como os Procons, por exemplo, dos juizados especiais e de organizações não governamentais que bem desempenhavam a função de buscar a efetividade da proteção dos consumidores.

Percebeu-se que a facilitação do acesso à justiça e a necessidade de uma resposta jurisdicional rápida teria uma ligação direta com a efetividade dos direitos dos consumidores, criando-se, por exemplo, os Juizados Especiais Cíveis e Criminais. Nesse sentido bem abordou José Carlos Maldonado de Carvalho:

\footnotetext{
A tutela individual do consumidor, assim, passa a ser prestada de forma mais efetiva, dando causa, em consequência da multiplicação de ações, a uma explosão de demandas judiciais, já que, além de causas de menor complexidade, foram também reveladas as causas que, até então, permaneciam em estado de hibernação. (2008, p. 157).
}

Com a criação dos juizados especiais pela Lei 9.099/95 a prestação jurisdicional ficou mais acessível ao consumidor. Se antes a burocracia, o alto custo da demanda, a necessidade da contratação de advogado para se postular em juízo configuravam um dos fatores desmotivadores da perseguição dos direitos dos consumidores, a diretriz principiológica dos juizados pautada na celeridade, informalidade e simplicidade relativizaram aquele cenário. 
O consumidor, em demandas de baixa complexidade, passou a poder reivindicar os seus direitos em feitos com valor atribuído a causa até 20 salários mínimos sem a necessidade do patrocínio de advogado, até eventual fase recursal e com a assistência de advogado nas demandas até 40 salários mínimos.

Muito embora existam críticas a esse modelo, no sentido de que seria uma falsa facilitação da defesa do consumidor, já que este não conhece a norma, o processo e a sua tramitação, é inegável o aspecto da acessibilidade do jurisdicionado em relação a demandas que antes eram desprezadas, causando relevante desconforto social.

O Código de Defesa do Consumidor, no seu art. 81, faz referência expressa a tutela individual do consumidor, de forma que prevê tanto a referida atuação individual, quanto a coletiva.

Art. 81. A defesa dos interesses e direitos dos consumidores e das vítimas poderá ser exercida em juízo individualmente, ou a título coletivo.

Frise-se, desde já, que embora o legislador tenha feito referência a defesa dos direitos ser promovida em juízo, vale dizer, na via judicial, essa não é restritiva e muito menos exige que o consumidor esgote eventual via administrativa para depois socorrer-se do judiciário.

Na busca da efetivação dos direitos dos consumidores diversas políticas de efetivação tem sido desenvolvidas, como a criação de postos dos Procons, núcleos de conciliação e mediação, além da própria arbitragem. Muito embora o Código de Defesa do Consumidor, no art. 51, VII aponte como abusiva a cláusula contratual que imponha, de forma compulsória, a arbitragem, não foi da intenção do legislador obstar a prática desse mecanismo de resolução de conflitos no sistema de consumo. Neste particular, bem ponderou José Geraldo Brito Filomeno:

Pode igualmente haver outros instrumentos não governamentais de proteção ou defesa
do consumidor, os quais também poderão intentar soluções de seu interesse. A Lei
n $9.307 / 97$, mais conhecida como "Lei de Arbitragem", em tese igualmente trata da
solução privada de conflitos, o que, todavia, conforme já expusemos em artigo
específico, merece algumas reservas, até porque o inciso VII do art. 51 do Código de
Defesa do Consumidor diz, expressamente, que são consideradas abusivas, dentre
outras, as cláusulas que "determinem a utilização compulsória de arbitragem". (2007,
p. 146).

Tem-se como certo que não apenas o segmento governamental detém a missão de efetivar os direitos dos consumidores, devendo recair também sobre o segmento privado. A perspectiva da funcionalização das empresas, o caminho inevitável de uma atuação pautada no viés da responsabilidade social, tem permitido uma transformação na postura do fornecedor no mercado de consumo, com o emprego de expedientes que aproximam o consumidor da satisfação dos seus direitos. 
A implantação dos serviços de atendimento ao consumidor, denominados de SAC's, serviu para dar guarida ao consumidor que antes se encontrava distante, em todos os sentidos, do fornecedor do produto adquirido ou do serviço contratado. Ressaltando a importância do fornecedor no sentido aqui exposto, João Batista de Almeida aponta que:

É inegável que ao fornecedor (à área privada, portanto) está reservado importante
papel nessa tarefa. Pode-se afirmar, sem exagero e sem medo de errar, que do maior
grau de conscientização do fornecedor depende o melhor nível de respeito aos
direitos do consumidor. (2003, p. 295).

Por certo, o campo de atuação de proteção do consumidor passa por atuações conjuntas do segmento público e privado, posto que o vetor desse segmento do direito está pautado na máxima da prevenção.

O legislador consumerista consagrou direitos básicos para o sujeito especial, objeto de proteção do Código, assegurando-lhe o acesso aos órgãos judiciários e administrativos, com vistas á prevenção ou reparação de danos, com atuação individual, coletiva e difusa. Para a materialização desse acesso, instituiu no art. $5^{\circ}$ da norma de proteção ao consumidor os seguintes instrumentos: Promotorias de justiça de Defesa do Consumidor, no âmbito do Ministério Público; delegacias de polícia especializadas no atendimento de consumidores vítimas de infrações penais de consumo; Juizados e Varas especializadas para a solução de litígios de consumo, dentre outros.

Porém, como dito alhures, essa proteção é desenvolvida também no âmbito coletivo. O art. 2, parágrafo único da Lei 8.078/90 apresenta disposição expressa no sentido de equiparar a qualidade de consumidor a coletividade de pessoas. Nestes termos dispões o referido dispositivo:

Equipara-se a consumidor a coletividade de pessoas, ainda que indetermináveis, que haja intervindo nas relações de consumo.

O referido dispositivo é a norma de abertura no sistema consumerista para atuação dos entes legitimados no art. 82 do Código de Defesa do Consumidor promoverem a defesa dos interesses e direitos dos consumidores no âmbito coletivo. Entre eles, destaca-se a atuação do Ministério Público e mais recentemente da Defensoria Pública, sem desprezar a relevância de atuação dos demais legitimados.

As relações de consumo se desenvolvem de forma massificada, com dimensões significativas. O novo modelo de consumo ultrapassa as fronteiras do Município, do Estado, do país, ganhando dimensões continentais. A velocidade com que as relações de consumo são entabuladas, o número de indivíduos que são envolvidos, a exemplo das relações dos consumidores dos serviços de seguro saúde, que conta com milhões de consumidores, bem 
evidenciam a necessidade de uma atuação coletiva e não apenas individualizada na tutela do consumidor.

Nessa perspectiva, instituiu-se interesses e direitos difusos, coletivos e individuais homogêneos, de forma que a tutela do consumidor se efetivasse de forma significativa. Desmembrando de forma explicativa esses direitos, Kazuo Watanabe ponderou que essa tutela:

\begin{abstract}
Abrange dois tipos de interesses ou direitos: a) os essencialmente coletivos, que são os 'difusos', definidos no inc. I do parágrafo único do art. 81 , e os 'coletivos' propriamente ditos, conceituados no inc. II do parágrafo único do art. 81 ; b) os de natureza coletiva apenas na forma em que são tutelados, que são os individuais homogêneos, definidos no inc. III do parágrafo único do art. 81.(1999, p. 718).
\end{abstract}

O devido enquadramento desses interesses revela-se útil na medida em que será capaz de produzir efeitos diversos as manifestações judiciais decorrente de demandas coletivas, latu sensu.

Cabe ressaltar que a temática de atuação de direitos difusos e coletivos não é nenhuma novidade instituída pelo Código de Defesa do Consumidor. O legislador consumerista apenas materializou de forma específica. Em verdade, os movimentos sociais que se fomentaram pelos Estados Unidos e alguns países da Europa, atentos, inclusive, as questões ambientais serviram de célula motivadora para atenções difusas e coletivas.

Assim, a tutela no âmbito coletivo do consumidor passou a exigir também uma reestruturação da abordagem processual. Os expedientes e instrumentos utilizados para a devida atuação individual em juízo não se demonstravam eficientes aos propósitos perseguidos com a tutela coletiva. Ganhou destaque a ação coletiva de consumo e a ação civil pública.

No caso da ação civil pública, que tem previsão constitucional e está regulada pela Lei 7.347/85, possui objetivos específicos e o seu manejo abarca interesses relevantes que envolvem o meio ambiente, o patrimônio público e a defesa do consumidor, dentre outros.

Ressalta-se a significativa relevância da tutela coletiva no âmbito do direito do consumidor, uma vez que milhares ou até mesmo milhões de consumidores passam a contar com um acesso a tutela jurisdicional de forma concentrada, sem ter que cada um desses consumidores propor ações individuais, com os custos que lhe são peculiares.

No tratamento das ações coletivas de consumo algumas questões processuais ganham destaque, na medida em que implementam regras próprias para a sistemática da defesa do consumidor. É o caso, por exemplo, da regulação da competência para a propositura da referida medida judicial. $\mathrm{O}$ art. 93 do Código de Defesa do Consumidor apresenta o 
tratamento legal em relação à competência para conhecer da demanda coletiva, que em regra é instituída no foro do lugar onde ocorreu ou deva ocorrer o dano. Cabe ressaltar, que não obstante o tratamento dado pelo legislador encontre-se no capitulo pertinente as ações coletivas em defesa dos direitos individuais homogêneos, é cristalino o seu enquadramento no que toca a defesa dos interesses difusos e coletivos.

Outro aspecto relevante no que toca a tutela coletiva reside no enquadramento dos efeitos da coisa julgada. O legislador, no art. 103 do Código de Defesa do Consumidor, estabeleceu de forma pontual os efeitos da coisa julgada conforme os interesses e direitos envolvidos. Assim, terá a sentença em demanda coletiva efeitos erga omnes quando envolver direitos difusos e os individuais homogêneos, ao passo em que contará com efeitos ultra partes nos casos de direitos coletivos.

Não obstante aos efeitos declinados, cabe apontar que há inexistência de prejuízo as demandas individuais eventualmente manejadas pelos consumidores. Nesse sentido, bem aponta José Carlos Maldonado de Carvalho:

\begin{abstract}
Os efeitos da coisa julgada erga omnes e ultra partes, segundo a norma do $\$ 2^{\circ}$ do artigo em comento, não prejudicarão interesses e direitos individuais dos integrantes da coletividade, do grupo, categoria ou classe. Cabe aqui sublinhar, ainda, que os efeitos da coisa julgada, uma vez que a ação coletiva não induz litispendência em relação a ações individuais, não prejudicarão as ações de indenização por danos pessoalmente sofridos, propostas individualmente, salvo se versar sobre interesses individuais homogêneos, quanto aos lesados que intervieram na ação. (2008, p. 182).
\end{abstract}

Vale ressaltar que na hipótese de acolhimento da pretensão coletiva, o sistema jurídico assegura que aqueles que foram vítimas, bem como seus herdeiros e sucessores, possam promover a liquidação e a execução da sentença, nos termos dispostos pelo art. 97 do Código de Defesa do Consumidor.

Apresentada a estrutura da tutela do consumidor, que pode se dar de forma individual ou coletiva, mister se faz demonstrar os meios instrumentalizados pelo legislador no aspecto processual para a busca da efetividade da proteção dos direitos do consumidor.

\title{
3. OS MEIOS DE FACILITAÇÃO DA DEFESA DOS DIREITOS DOS CONSUMIDORES
}

O sistema de consumo materializou medidas processuais eficientes, que ao lado de outras regras de direito material tornam o Código de Defesa do Consumidor um micro sistema jurídico peculiar. 
O Código de Defesa do Consumidor dispõe no art. $6^{\circ}$ um rol exemplificativo de direitos básicos do consumidor, fixando, portanto, um roteiro mínimo que deve ser assegurado e reconhecido ao sujeito especial destinatário da proteção legal.

Há que se observar que diante da natureza da norma de consumo, bem como do caráter principiológico do Código de Defesa do Consumidor, a intenção do legislador foi constituir uma norma aberta, que permitisse ao operador do direito materializar o comando constitucional de proteção e defesa do consumidor.

Sérgio Cavalieri Filho ao promover o seu entendimento por direitos básicos afirma que:

\begin{abstract}
Direitos básicos dos consumidores são aqueles interesses mínimos, materiais ou instrumentais, relacionados a direitos fundamentais universalmente consagrados que, diante de sua relevância social e econômica, pretendeu o legislador ver expressamente tutelados. (2011, p. 90).
\end{abstract}

Por se tratar de um rol exemplificativo, como dito alhures, evidentemente não esgotaremos no presente escrito todas as circunstâncias, no âmbito processual, que norteiam a facilitação da defesa dos direitos dos consumidores, mas nos dedicaremos a abordar os aspectos relevantes a respeito da vedação a denunciação da lide nas demandadas de consumo, a regulação do foro privilegiado do consumidor e, principalmente a questão da inversão do ônus da prova.

Com esse proposito, o presente tópico foi subdividido nos itens a seguir expostos, visando apresentar de forma mais harmônica e sintetizada os aludidos meios de facilitação da defesa dos direitos dos consumidores.

\title{
3.1 Vedação a denunciação da lide
}

O sistema processual civil brasileiro consagrou a figura da intervenção de terceiros, modalidade em que enquadra a pessoa estranha a uma lide originária, por não ter sido integrada por litisconsórcio, estando prevista a partir do art. 56 ao 80 do Código de Processo Civil.

Porém não é qualquer pessoa estranha que adentra na lide. No dizer de Luiz Rodrigues Wambier (2002, p. 249), "na intervenção de terceiros ocorre como que a intromissão de terceiro, voluntária ou coativamente, havendo de existir interesse jurídico que justifique essa intervenção".

A intervenção de terceiros, de forma pontual, apresenta-se de cinco formas: pela assistência, oposição, nomeação à autoria, denunciação da lide e o chamamento ao processo. 
Não é proposito do presente escrito abordar todas as modalidades de intervenção de terceiro, razão pela qual dedicaremos esse tópico tão somente a denunciação da lide, em razão de possuir implicações específicas com o direito do consumidor.

Regulada no Código de Processo Civil a partir do art. 70, a denunciação da lide se apresenta de forma impositiva legal, já que o legislador declina que ela será obrigatória nas circunstâncias ali previstas, muito embora em alguns casos, tanto a doutrina quanto a jurisprudência, aponte como liberalidade da parte interessada.

A denunciação da lide, em verdade, tem como proposito introduzir uma nova lide em uma já existente, com o fito de assegurar eventual direito de regresso, podendo ser manejada tanto pelo autor, quanto pelo réu.

Se a sua essência está em assegurar a via de regresso, no sistema de consumo a sua verificação e pertinência ficam comprometidas. O sistema de consumo, no âmbito da responsabilidade civil está estruturado na responsabilidade objetiva e solidária dos fornecedores frente aos consumidores.

Ora, se ao consumidor, em regra, lhe é assegurado optar em face de qual fornecedor irá demandar e, diante da responsabilidade objetiva o fornecedor responde pelos danos causados ao consumidor, independentemente de culpa, torna-se manifestamente desvantajoso para o consumidor o manejo da denunciação da lide.

Não obstante o instituto demonstre a ideia de que permitiria uma economia processual, já que na hipótese da denunciação da lide o magistrado deverá, simultaneamente, sentenciar a lide principal e a denunciação da lide, na prática tal expediente implica em ônus excessivo para o consumidor, posto que a marcha processual poderia ter sido conduzida com menos atos processuais.

Sérgio Cavalieri Filho ao enfrentar de forma especifica o tema em questão, sinaliza que:

\footnotetext{
A denunciação da lide não oferece os benefícios proclamados pelos processualistas. Se, por um lado, oferece economia processual para o denunciante, ao pegar carona no processo do autor, para este produz efeito contrário, pois retarda significativamente o andamento do seu processo, aumenta a complexidade probatória, além de outros inconveniente. (2011, p. 346).
}

Analisando a sistemática legal percebe-se que o legislador infraconstitucional foi atento a condição do consumidor e a necessidade de se obter uma prestação jurisdicional célere e eficiente para esse sujeito. Nesse particular, no art. 88 do Código de Defesa do Consumidor foi vedada expressamente a promoção da denunciação da lide. Oportuna é a transcrição do referido dispositivo. 
Art. $88 \mathrm{Na}$ hipótese do art. 13, parágrafo único, deste Código, a ação de regresso poderá ser ajuizada em processo autônomo, facultada a possibilidade de prosseguirse nos mesmos autos, vedada a denunciação da lide.

Muito embora a vedação seja expressa, o que legitimaria de forma fácil e tranquila a compreensão de que nas demandas de consumo envolvendo pretensões indenizatórias, proibido estaria a incidência da denunciação da lide, o Superior Tribunal de Justiça - STJ tem admitido interpretação literal ao referido dispositivo, entendendo que a referida restrição somente teria campo na hipótese de fato ou defeito do produto, afastando-se a vedação para a hipótese de vício, bem como para eventual defeito do serviço.

A sistemática processual ainda veda a denunciação da lide, assim como as demais modalidades de intervenção de terceiros, salvo a assistência, quando a demanda de consumo tramitar pelo rito sumário, tendo o legislador expressamente previsto a referida restrição no art. 280 do Código de Processo Civil.

No que toca, ainda, a lide de consumo é preciso apontar que a Lei 9.099/95, que dispõe sobre os juizados especiais, no seu art. 10, não admite qualquer forma de intervenção de terceiros, tendo em vista os princípios norteadores do sistema.

É importante ressaltar que essa vedação tem como proposito assegurar a efetividade dos direitos dos consumidores concedendo-lhe uma tutela jurisdicional célere, desprovida de entraves que em nada lhes seriam útil.

Porém, as peculiaridades da norma de consumo não ficam por aí, o legislador consumerista instituiu outro importante facilitador da defesa dos direitos do consumidor, como será adiante demonstrado.

\subsection{Foro privilegiado}

O sistema processual geral regulado pelo Código de Processo Civil instituiu no art. 94, ao iniciar a seção que trata da competência territorial, a regra da fixação do foro do domicílio do réu para promoções de ações fundadas em direito pessoal. Assim dispõe o referido dispositivo:

Art. 94. A ação fundada em direito pessoal e a ação fundada em direito real sobre bens móveis serão propostas, em regra, no foro do domicílio do réu.

Por certo, o legislador valeu-se de um critério territorial para verificar a competência dos órgãos jurisdicionais, face às diversas disposições topográficas dos órgãos. Wambier (2002, p. 89) sinaliza que "assim como a jurisdição brasileira tem como limite o território 
nacional (competência internacional), os juízes nacionais têm limitações ao exercício da função jurisdicional em razão do território"

Observando uma perspectiva de relação processual geral, em que, em tese, os sujeitos estariam em condições semelhantes, a concepção de se instituir como regra o foro do domicílio do réu é salutar, considerando, inclusive, os ditames constitucionais a legitimar o exercício da ampla defesa e do contraditório.

Porém, na sistemática das relações de consumo em que um dos sujeitos é reconhecido legalmente pela característica da vulnerabilidade e pelo fato de estar em diversas circunstâncias como hipossuficiente, a manutenção da regra geral instituída no Código de Processo Civil, simplesmente inviabilizaria o acesso do consumidor a prestação jurisdicional.

A imaginar, por exemplo, a situação do consumidor que em viagem de turismo adquiri produtos ou simplesmente contrata serviços e estes são realizados de forma viciada ou defeituosa, ao retorno ao seu domicílio, deveria se deslocar ao domicílio do réu para promover a demanda judicial pertinente, o que implicaria elevados custos, necessidade de deslocamento, etc. Por certo, muitos consumidores desistiriam de postular em juízo pela defesa de seus direitos.

Atento a essa circunstância, o legislador infraconstitucional relativizou a regra instituída no Código de Processo Civil e estabeleceu no âmbito do Código de Defesa do Consumidor, no inciso I do art. 101, o foro privilegiado para o consumidor, ao dispor:

Art. 101. Na ação de responsabilidade civil do fornecedor de produtos e serviços, sem prejuízo do disposto nos Capítulos I e II deste Título, serão observadas as seguintes normas:

I - a ação pode ser proposta no domicílio do autor.

Apresenta-se de forma relevante para a política de proteção e defesa do consumidor o estabelecimento da prerrogativa de foro para o consumidor, ainda mais em um sistema de consumo de massa onde os produtos e os serviços dos fornecedores ganharam dimensões continentais, não existindo, praticamente, mais limites de fronteiras para a atuação do fornecedor.

Exigir que o consumidor se adequasse a sistemática processual geral seria o mesmo que conceder-lhe direitos, mais privá-lo de usá-lo. Como se observa da dicção do referido dispositivo, o consumidor poderá optar por propor a ação no seu domicílio, ou seja, quando, por alguma circunstância lhe for favorável demandar em foro diverso daquele previsto no referido dispositivo, autorizado estará.

Enfrentando o tema, Ellen Cristina Gonçalves Pires assevera que: 
O foro do domicílio do autor é regra que beneficia o consumidor, dentro da orientação fixada no inciso VII do art. $6^{\circ}$ do Código de Defesa do Consumidor, de facilitar o acesso aos órgãos judiciários. Trata-se, porém, de opção dada ao consumidor, que poderá rejeitá-la, em benefício do réu, elegendo a regra geral, que é a do domicílio do demandado, conforme art. 94 do Código de processo Civil. (2006, p. 120).

Como se percebe, a nítida intenção do legislador foi de facilitar o acesso do consumidor à justiça. No que toca ao âmbito de atuação da relativização instituída no Código de Defesa do Consumidor, a disposição da prerrogativa de foro deve ser observada em toda e qualquer demanda de consumo, tanto no que toca a responsabilidade por fato ou defeito, quanto na responsabilidade por vício, não tendo o legislador fragmentado o âmbito de pertinência da prerrogativa, o que foi manifestamente benéfico ao consumidor.

Não se pode desprezar o fato de que a maioria das relações de consumo na atualidade é firmada com base em contratos de adesão, com conteúdo preestabelecido pelo fornecedor. A princípio, não há nenhuma ilegalidade na celebração de negócios jurídicos lastreado pelo contrato de adesão, tanto assim que o Código Civil, bem como o próprio Código de Defesa do Consumidor apresentam disposição expressa a respeito dessa figura contratual.

O que se deve observar nos contratos de adesão celebrados com consumidores é se neles existem disposição contratual pela fixação de cláusula de eleição de foro, de forma que não seja prejudicial ao consumidor ou até mesmo afronte a prerrogativa instituída no inciso I do art. 101 do Código de Defesa do Consumidor.

Caberá ao julgador, quando do conhecimento da demanda de consumo, verificar se eventual disposição concernente a fixação de foro, estabelecida no corpo de contrato de adesão, é prejudicial ao consumidor, para no exercício da sua atividade jurisdicional promover a corretiva devida, afastando a incidência da disposição desfavorável ao sujeito vulnerável, in casu, o consumidor.

Essa atuação desejada do julgador decorre da natureza da norma de consumo e das peculiaridades instituídas no sistema jurídico consumerista pelo Código de Defesa do Consumidor. Sérgio Cavalieri Filho bem demonstrou tal circunstância ao concluir que:

\footnotetext{
Por serem de ordem pública e interesse social as normas do Código do Consumidor, vale dizer, de observância necessária, dev o juiz aplica-las de ofício, decretando a nulidade das cláusulas contratuais que dificultem a defesa do consumidor, independentemente de provocação, estando aí incluído o foro de eleição previsto no contrato de adesão, porquanto significa dificuldade de acesso à justiça. (2011, p. $343)$.
}

No mesmo movimento de relativização da regra geral estabelecida no Código de Processo Civil no que toca a fixação do foro, para a competência territorial, o legislador 
infraconstitucional ampliou as hipóteses de tratamento diferenciado do art. 94 da citada norma.

A Lei 9.099/95, que dispõe a respeito dos juizados especiais estabeleceu no art. $4^{\circ}$ a competência de foro conforme a regra geral, mas no seu inciso III a relativizou, concedendo ao autor a prerrogativa de demandar em seu domicílio, ou no do local do ato ou fato, nas ações para reparação de dano de qualquer natureza.

Como a referida lei é norteada por princípios específicos, tais como o da celeridade, informalidade e economia processual, a disposição supra bem evidencia o proposito do legislador em facilitar o acesso à justiça, que não foi apenas restrito as demandas de consumo, mas, também, aquelas cíveis de baixa complexidade e inseridas no rol de competência dos juizados especiais.

Em arremate de tópico, pondera-se que a instituição da prerrogativa de foro em benefício do consumidor nas demandas de consumo, reveste-se de grande importância para a concretização da facilitação dos meios de defesa do consumidor em juízo.

\subsection{Inversão do ônus da prova}

Um dos temas mais interessantes na abordagem processual reside justamente no capítulo da teoria da prova, posto que na marcha processual a produção ou dilação probatória estará diretamente ligada, por vezes, ao resultado útil da demanda.

Não é por outra razão que o operador do direito deve se dedicar a compreensão do fenômeno probatório no curso processual, bem como das regras de disposição do onus probandi.

Marcelo Abelha Rodrigues, bem sintetiza o aspecto de destaque da prova no direito processual, discorrendo que:

\footnotetext{
a teoria geral da prova constitui-se num dos temas mais instigantes do direito processual civil, não só pelas suas particularidades, mas pela importância que empresta à ciência do processo civil, na exata medida em que se posiciona como elemento importantíssimo na busca da verdade e, portanto, na aproximação da justiça com o jurisdicionado. (2000, p. 167).
}

A concepção de prova, por certo, ultrapassa a perspectiva apenas jurídica, uma vez que está integrada a essência dos atos da vida humana, sendo objeto de verificação a todo instante nos atos ou fatos da vida.

Se assim se apresenta, com maior nitidez é a verificação da prova no processo jurisdicional. Wambier (2002, p. 439) conceitua prova "como o instrumento processual 
adequado a levar ao conhecimento do juiz os fatos que envolvem a relação jurídica objeto da atuação jurisdicional”.

No estudo da teoria geral da prova, a distribuição do ônus probatório sempre foi tema de discussões, na medida em que, por vezes, o sujeito não alcançava a sua pretensão material, por não conseguir se desincumbir do seu ônus probatório fixado pela lei.

O ônus apresenta-se como um encargo para as partes na atuação processual, que no sistema geral está disposto no art. 333 do Código de Processo Civil. Assim dispôs o legislador:

Art. 333. O ônus da prova incumbe:

I - ao autor, quanto ao fato constitutivo do seu direito;

II - ao réu, quanto à existência de fato impeditivo, modificativo ou extintivo do direito do autor.

Tamanha a relevância da regra instituída no referido dispositivo legal, que o próprio legislador estabeleceu a nulidade de eventual convenção que promova distribuição diversa daquela disposta, quando se tratar de direito indisponível e quando se tornar excessivamente difícil a uma parte o exercício do direito.

A referida regra de distribuição pode ser denominada como estática, ou seja, fixa, parada, uma vez que o legislador estabeleceu na norma a quem cabe se desincumbir do ônus probatório. Por certo, essa é a regra geral do sistema processual civil brasileiro, inclusive, no que toca a seara consumerista.

Fredie Didier Jr., bem esclarece as circunstâncias da regra de distribuição do ônus da prova. Em sua obra, aduz que:

\footnotetext{
Compete, em regra, a cada uma das partes o ônus de fornecer os elementos de prova das alegações de fato que fizer. A parte que alega deve buscar os meios necessários para convencer o juiz da veracidade do fato deduzido como base da sua pretensão/exceção, afinal é a maior interessada no seu reconhecimento e acolhimento. (2011, p. 80).
}

No direito do consumidor, a vulnerabilidade e a hipossuficiência do sujeito destinatário da norma protetiva, reclamava por uma necessidade de mudança no sistema de distribuição do ônus probatório, tendo em vista, que em muitas situações, a aplicabilidade da regra geral instituída no Código de Processo Civil, afastava o consumidor da satisfação dos seus direitos.

Percebeu-se que a regra geral não era capaz de atender a efetividade reclamada pelo novo modelo jurídico, o da relação jurídica de consumo. No proposito de atender ao comando constitucional estabelecido no art. 5, XXXII da Constituição Federal de 1988 o legislador consumerista estabeleceu no art. $6^{\circ}$, VIII da Lei 8.078/90, como direito básico do consumidor, a facilitação da defesa de seus direitos, inclusive, com a inversão do ônus da prova. 
Com esse norte, foi consagrado expressamente no Código de Defesa do Consumidor a possibilidade de inversão do ônus da prova em duas possibilidades, no art. $6^{\circ}$, VIII e no art. 38.

Percebe-se, em verdade, duas espécies ou modalidades de inversão do ônus da prova no sistema de consumo, a inversão ope legis e a inversão ope judicis. A primeira decorre de expressa determinação legal, ou seja, é quando o legislador aponta que para certa e determinada situação o ônus probatório está distribuído de forma diversa da regra geral instituída no art. 333 do Código de Processo Civil. Afrânio Carlos Moreira Thomaz bem clareia esse entendimento:

Sobre a inversão do ônus da prova em sede judicial, tal medida, que veio a excepcionar a regra geral contida no art. 333, I, do CPC, pode se dar ope legis ou ope judicis. A inversão do ônus da prova ope legis é aquela já expressamente prevista no texto do CDC, e independe, para a sua aplicação, de qualquer avaliação subjetiva por parte do juiz, não sendo adotada, pois, "a seu critério", "segundo as regras ordinárias de experiência". A lei é categórica e incisiva a esse respeito, determinando claramente a inversão nos casos por ela enumerados. (2009, p. 178).

Tem-se como exemplo, no âmbito do direito do consumidor, de inversão ope legis a regra disposta no art. 38 da Lei 8.078/90. Ao estabelecer regras para a prática da publicidade como meio de oferta no sistema de consumo, o legislador impôs o ônus de fazer prova da veracidade e correção da informação ou comunicação publicitária a quem as patrocina, ou seja, o fornecedor.

Percebe-se a nítida inversão do ônus da prova, uma vez que diante de eventual alegação do consumidor de que a publicidade patrocinada pelo fornecedor é enganosa ou abusiva, pela regra geral, caberia ao autor, portanto o consumidor, fazer prova da ilicitude. Contudo, tal dilação probatória seria extremamente difícil ou até mesmo impossível para o consumidor se desincumbir, já que não possui acesso aos dados e elementos da mensagem publicitária.

Assim, visando facilitar a defesa dos direitos do consumidor, foi invertido, de forma legal, ou seja, por determinação da lei, independentemente de requerimento do consumidor ou de vontade do julgador, a inversão do ônus probatório.

Por outro lado, a inversão ope judicis revela-se na forma disposta no art. $6^{\circ}$, VIII do Código de Defesa do Consumidor. Para que ocorra essa modalidade de inversão faz-se necessária manifestação judicial fundamentada, com observância dos requisitos autorizadores previsto na referida norma.

Cabe ressaltar que no sistema consumerista a regra da distribuição do ônus probatório é a regulada pelo Código de Processo Civil, na forma disposta no seu art. 333, sendo a 
inversão com aplicabilidade em caráter excepcional. Entender de outra forma seria desprezar o comando do art. $6^{\circ}$, VIII do Código de Defesa do Consumidor, que instituiu requisitos expressos para que a inversão se efetive. Neste particular, oportuna a transcrição do referido dispositivo legal:

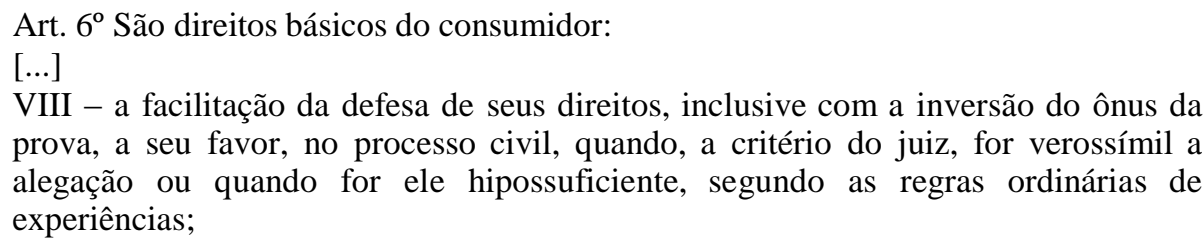

É preciso compreender adequadamente as disposições do art. $6^{\circ}$, VIII, posto que o legislador preencheu no referido comando normativo elementos relevantes para a implementação da inversão probatória.

Primeiramente, cabe apontar, que a inversão do ônus da prova referenciada pode, com expressão de poder-dever, ser aplicada de ofício pelo magistrado, independentemente de provocação do consumidor. Tal ilação é possível a partir da constatação da natureza da norma de consumo como sendo de ordem pública e de interesse social.

Aplicada de ofício, ou a requerimento do consumidor, esta somente pode ser concedida em seu favor, por se tratar de um direito básico do consumidor, e no âmbito do processo civil. O legislador promoveu essa ressalva de forma expressa, tendo em vista a característica de microsistema da Lei 8.078/90, que consagra norma de caráter material, processual, penal e administrativo.

Por certo, no âmbito da tutela penal do consumidor, não será possível inverter o ônus da prova, sob pena de ofensa direta a comando constitucional, que instituiu como direito fundamental a presunção de inocência.

O legislador, ao admitir a inversão do ônus da prova no Código de Defesa do Consumidor, na modalidade ope judicis, passou a exigir a presença de requisitos autorizadores, quais sejam, a verossimilhança das alegações do consumidor ou a sua hipossuficiência, que não precisam estar presentes de forma cumulativa.

A verossimilhança das alegações deve ser compreendida como alegações com aparência de verdade ou com cheiro de verdade. Percebe-se que o magistrado deve buscar nas afirmações trazidas pelo consumidor um cunho de aparência ou evidencia de serem verdadeiras, não precisando, evidentemente, serem de logo provadas, até porque se busca justamente a inversão do ônus da prova.

Enquadramento adequado ao conceito de verossimilhança é trazido por Sergio Cavalieri Filho: 


\begin{abstract}
Verossimilhança é a aparência de veracidade que resulta de uma situação fática com base naquilo que normalmente acontece, ou, ainda, porque um fato é ordinariamente a consequência de um outro, de sorte que, existente este, admite-se a existência daquele, a menos que a outra parte demonstre o contrário. Trata-se, como vê, de conceito jurídico indeterminado, cujo conteúdo há de ser fixado pelo juiz, segundo as regras ordinárias de experiência, em face do caso concreto. Em suma, verossímil é aquilo que é crível ou aceitável em face de uma realidade fática. Não se trata de prova robusta ou definitiva, mas da chamada prova de primeira aparência, prova de verossimilhança, decorrente das regras da experiência comum, que permite um juízo de probabilidade. (2011, p. 352).
\end{abstract}

O outro requisito, a hipossuficiência, deve ser compreendido na seara do direito do consumidor como sendo o estado de dificuldade ou impossibilidade do consumidor se desincumbir do seu ônus probatório geral. A hipossuficiência está atrelada, portanto, ao campo probatório, sendo uma circunstância de fato, a ser analisada no caso concreto. Esse requisito não pode ser confundido com a característica da vulnerabilidade, que é inerente a todo consumidor. Aduz, inclusive, Roberto Senise Lisboa que:

\begin{abstract}
Enquanto o legislador consumerista considera todo consumidor a parte vulnerável na relação de consumo, independentemente das diferenças sociais ou econômicas existentes entre os inúmeros consumidores do mercado, um tratamento diverso foi legalmente conferido ao consumidor hipossuficiente. [...] em outras palavras: não é sempre que o consumidor pode ser considerado hipossuficiente, mas ele sempre é vulnerável. O consumidor vulnerável pode ser hipossuficiente, ou não. A lei não entende que a hipossuficiência equivale à vulnerabilidade. (2006, p. 99).
\end{abstract}

Hipossuficiência, para o direito, apresenta múltiplas dimensões. No sistema jurídico laboral, está reservada a constatação da discrepância material entre o empregado e o empregador, tendo a norma trabalhista o objetivo de equilibrar a latente desigualdade, concedendo instrumentos eficientes para esse objetivo. Contudo, a hipossuficiência também está associada ao estado econômico do indivíduo, servindo para lhe identificar como possível beneficiário da assistência judiciária gratuita, como consagrado na Lei 1.060/50.

Ambos os requisitos devem ser apurados a partir da análise do magistrado, que os identificando deverá fundamentar a sua decisão pela possibilidade de inversão do ônus da prova. O julgador deverá valer-se das regras ordinárias de experiência, na forma disposta no art. $6^{\circ}$, VIII, que deve ser compreendida como as experiências desenvolvidas a partir do seu labor habitual.

Como se observa, a inversão não é regra no sistema consumerista, devendo estar presente um ou outro, ou ambos os requisitos autorizadores previstos na norma. André Bonelli Rebouças bem sintetiza esse cenário ao aduzir que:

Se o autor não for hipossuficiente ou se não forem verossímeis suas alegações, permanecerá a regra geral do CPC, cabendo a ele, consumidor, o ônus da prova dos fatos constitutivos do seu direito. Se, todavia, é o demandante um hipossuficiente, ou sendo plausíveis suas articulações fatuais, terá o direito à inversão, tudo consoante as tais regras de experiência. Mas quando e como saber sobre a sua 
hipossuficiência? Quando e como certificar-se da verossimilhança do que diz? Só a partir do momento em que o juiz, a seu critério, segundo as regras ordinárias de experiência, assim o decida. Só desse modo é que terá o autor a convicção de que o encargo probandi já não é mais seu, sabendo aí, outrossim, também o réu que terá contra si operada a inversão. (2006, p.61).

De derradeiro sobre o tema, é necessário verificar qual o momento processual adequado para que o magistrado promova a inversão do ônus da prova, já que na modalidade ope judicis é necessário a manifestação judicial.

Correntes doutrinárias apontam a existência de dois entendimentos a respeito de momentos distintos para a efetivação da inversão do ônus da prova, denominados como regras de julgamento e de procedimento.

Há quem aponte que a prova no processo tem como destinatário o magistrado, podendo ele livremente escolher o momento para implementar a inversão do ônus probatório, inclusive, no momento da prolação da sentença, entendimento que é representado pela regra de julgamento.

Cabe observar que o entendimento da regra de julgamento promove, na prática, nítida violação a preceito fundamental que assegura aos litigantes o exercício da ampla defesa e do contraditório, consagrados constitucionalmente, na medida em que no momento da prolação da sentença já foi encerrada toda fase de produção das provas, sendo uma das partes surpreendida com inversão.

A intenção do legislador não foi suprir a necessidade de um sujeito da relação processual e onerar demasiadamente o outro. Humberto Theodoro Júnior contextualiza a inversão do ônus da prova como uma forma de reequilíbrio entre consumidores e fornecedores no sistema de consumo, asseverando que:

\footnotetext{
O mecanismo da inversão do ônus da prova se insere nessa política tutelar do consumidor e deve ser aplicado até quando seja necessário para superar a vulnerabilidade do consumidor e estabelecer seu equilíbrio processual em face do fornecedor. Não pode, evidentemente, ser um meio de impor um novo desequilíbrio na relação entre as partes, a tal ponto de atribuir ao fornecedor um encargo absurdo e insuscetível de desempenho. (THEODORO JÚNIOR, 2009, p. 217).
}

Para prevalecer o entendimento da regra de julgamento, parece necessário ao julgador, antes de prolatar a sentença, tendo ele visualizado os requisitos autorizadores da inversão do ônus da prova, intimar as partes, concedendo-lhe prazo para que possa se desincumbir do novo ônus imposto com a inversão, atendendo assim os preceitos fundamentais alhures apontado.

Por outro lado, como regra de procedimento, reside o entendimento de que o magistrado deverá posicionar-se a respeito de eventual inversão do ônus da prova no 
momento do despacho saneador, quando forem fixados os pontos controvertidos da demanda, antecedendo a fase instrutória do feito, permitindo que as partes tenham ciência de logo a respeito da carga probatória que terão de suportar.

Percebe-se que esse entendimento guarda maior consonância com os ditames constitucionais, assegurando, inclusive, uma maior segurança jurídica processual, evitando surpresas indesejadas e deixando de exigir, por exemplo, do fornecedor que ele seja um superréu.

Com propriedade, Roberto Senise Lisboa posiciona-se no seguinte sentido:

\begin{abstract}
A inversão do ônus da prova deve ser conferida até o final da fase postulatória, para não se surpreender indevidamente a outra parte, até mesmo porque ao juiz é facultada, ao final do processo, a conversão do julgamento em diligência. A aceitação do pedido de inversão do ônus da prova após o início da fase instrutória importa em tumulto processual e atenta contra os princípios constitucionais do due process of law, do contraditório e da ampla defesa. (2006, p.111).
\end{abstract}

É certo, que a inversão do ônus da prova irá proporcionar efeitos específicos para o consumidor, facilitando o seu acesso a justiça, já que no sistema de consumo, pelo adoção da responsabilidade objetiva, como regra, está o consumidor dispensado de fazer prova da culpa do fornecedor, bem como em circunstâncias específicas estará dispensado da prova referente ao nexo de causalidade, mas, não o dispensará de provar o dano, salvo nas demandas de responsabilidade civil que aplique-se a figura do dano in re ipsa.

Sob essa perspectiva, a inversão do ônus da prova se apresenta como um relevante mecanismo de facilitação da defesa dos direitos dos consumidores.

\title{
4. CONSIDERAÇÕES FINAIS
}

Visualizar os aspectos processuais que norteiam a peculiaridade de um ramo do direito especifico como é o direito do consumidor, habilita o operador do direito a compreender a necessidade de realizar uma releitura dos instrumentos colocados a disposição dos consumidores para o alcance da satisfação de seus direitos.

Assim, por todo o exposto no presente escrito percebe-se que de nada adiantaria os sistemas jurídicos implementar normas de proteção e defesa dos direitos dos consumidores se não fosse revistos os instrumentos processuais.

Perceber que as relações jurídicas modernas, em especial a de consumo, reclamam por uma superação de institutos tradicionais da teoria geral do processo e destinar as demandas mecanismos específicos que assegurem a efetividade dos direitos consagrados pelos 
consumidores, tem se apresentado como algo que exige especial atenção do operador do direito.

Os meios de facilitação da defesa dos direitos dos consumidores, precisam ser aplicados de forma efetiva, caso contrário as diretrizes constitucionais de defesa e proteção do consumidor estarão comprometidas.

No sistema jurídico brasileiro, o Código de Defesa do Consumidor promoveu relevante evolução nos aspectos processuais, com o fito de facilitar o acesso a justiça, promover a solução dos litígios de forma célere e viabilizar a concretização de direitos.

A tutela individual e coletiva do consumidor revela-se como mecanismo eficiente em um sistema de consumo massificado, instituindo legitimidade a agentes específicos na postulação da defesa de direitos e interesses dos consumidores.

Destaque efetivo foi dado a possibilidade de inversão do ônus da prova, na forma prevista na norma consumerista, por refletir um dos meios mais importantes de facilitação do acesso do consumidor a justiça e a materialização dos seus direitos, face a sua condição de vulnerável, por excelência e, de hipossuficiente em dadas circunstâncias.

Os demais meios de facilitação da defesa de direitos enfrentados evidenciam a preocupação do sistema protetivo em atender o comando constitucional de determinação de proteção e defesa do consumidor. Dessa forma, é nítido o caráter, eminentemente, tutelar da norma consumerista.

\section{REFERÊNCIAS}

ALMEIDA, João Batista de. A Proteção Jurídica do Consumidor. 4.ed. rev. atual. e amp. São Paulo: Saraiva, 2003.

CARVALHO, José Carlos Maldonado de. Direito do consumidor. Fundamentos doutrinários e visão jurisprudencial, $3^{\text {a }}$ edição, Rio de Janeiro: Editora Lumen Juris, 2008.

CAVALIERI FILHO, Sérgio. Programa de Direito do Consumidor, $3^{\text {a }}$ edição, São Paulo: Atlas, 2011.

DIDIER JR, Fredie. Curso de direito processual civil. Teoria da prova, direito probatório, teoria do precedente, decisão judicial, coisa julgada e antecipação dos efeitos da tutela, V2, $\mathbf{6}^{\mathbf{a}}$ ed. Salvador: Editora Juspodivm, 2011. 
FILOMENO, José Geraldo de Brito. In: GRINOVER, Ada Pelegrini. Código Brasileiro de Defesa do Consumidor comentado pelos autores do anteprojeto. 9. Ed. Rio de Janeiro: Forense Universitária, 2007.

, Curso fundamental de direito do consumidor. São Paulo: Editora Atlas, 2007.

LISBOA, Roberto Senise. Responsabilidade Civil nas Relações de Consumo. São Paulo: Revista dos Tribunais, 2006.

PIRES, Ellen Cristina Gonçalves. O Direito do consumidor e os juizados especiais cíveis. São Paulo: IOB Thomson, 2006.

REBOUÇAS, André Bonelli. Questões sobre o ônus da prova no Código de defesa do Consumidor. Rio de Janeiro: Forense, 2006.

RODRIGUES, Marcelo Abelha. Elementos de direito processual civil. V.2. São Paulo: Editora Revista dos Tribunais, 2000.

THEODORO JÚNIOR, Humberto. Direitos do Consumidor: a busca de um ponto de equilíbrio entre as garantias do Código de Defesa do Consumidor e os princípios gerais do Direito civil e do Direito processual. Rio de Janeiro: Forense, 2009.

THOMAZ, Afrânio Carlos Moreira. Lições de direito do consumidor. Rio de Janeiro: Editora Lumen Juris, 2009.

WAMBIER, Luiz Rodrigues. Curco avançado de proceso civil, volumen 1. $5^{\text {a }}$ ed. São Paulo: Editora Revista dos Tribunais, 2002.

WATANABE, Kazuo. Código Brasileiro de Defesa do Consumidor comentado pelos autores do anteprojeto. 6. Ed., Rio de Janeiro: Forense Universitária, 1999. 